Available online at GSC Online Press Directory

GSC Biological and Pharmaceutical Sciences

e-ISSN: 2581-3250, CODEN (USA): GBPSC2

Journal homepage: https://www.gsconlinepress.com/journals/gscbps

(RESEARCH ARTICLE)

\title{
Systematic study of the diatoms (Bacillariophyta) of Joal-Fadiouth Lagoon (Senegal)
}

Gueye Madiop *, Ba Ngansoumana, Ngom Ablaye, Abdou Salam Ali Mohamed, Mbaye Mame Samba and Noba Kandioura

Laboratoire de Botanique - Biodiversité, Département de Biologie Végétale, Faculté des Sciences et Techniques, Université Cheikh Anta Diop, BP 5005, Dakar-Fann, Sénégal.

Publication history: Received on 10 July 2020; revised on 19 July 2020; accepted on 21 July 2020

Article DOI: https://doi.org/10.30574/gscbps.2020.12.1.0218

\begin{abstract}
This work constitutes a first study on the diatoms of Joal-Fadiouth Lagoon (Senegal). It was undertaken to describe, identify and determine the taxonomic composition of these diatoms. Observation of the samples collected between March and June 2013 made it possible to inventory 21 species belonging to 18 genera and divided into 13 families, 11 orders and 3 classes. These 21 species are new for the microflora of Joal-Fadiouth Lagoon.
\end{abstract}

Keywords: Systematic study; Diatoms; Lagoon; Joal-Fadiouth; Senegal.

\section{Introduction}

Relationship between biodiversity and functioning of ecosystems being a fundamental ecological question, to understand the structure and functioning of an ecosystem, it's essential to know the different elements that compose it [1]. Phytoplankton occupies a central place in all the problems of environmental imbalances at the interface between continent and marine environment [2]. Lagoons, estuaries and mangroves, characterized by a relatively diverse phytobenthos community dominated by diatoms [3], can also play a very important role in the proper functioning of the fishery resources of the continental shelf. Knowledge of diatoms in these coastal areas is therefore essential. The objective of this work is to describe, identify and determine the taxonomic composition of the diatoms of Joal-Fadiouth Lagoon.

\section{Material and methods}

The study was carried out in Joal-Fadiouth Lagoon located on the Petite Côte, $114 \mathrm{~km}$ southeast of Dakar (Senegal); the Lagoon presents an inverse hydrological functioning characteristic of a lagoon-estuarine system where marine influences predominate and are permanent [4]. Six samples (phytoplankton and phytobenthos) were collected (MarchJune 2013) and fixed (formalin 4\%). Sub-samples underwent a treatment of cleaning of the frustules by combination of calcination to chemical attack of the organic matter, before being mounted with Canada Balsam to prepare permanent slides for microscopy. The systematic arrangement of the diatoms list was made by according to [6].

\section{Results and discussion}

\subsection{Description and identification of taxa}

Phylum: Bacillariophyta

\footnotetext{
${ }^{*}$ Corresponding author: Gueye Madiop
} 
Class: Coscinodiscophyceae

Order: Melosirales

Family: Melosiraceae

Melosira crenulata (Ehr.) Kuetz (Figure 1A)

References: [7]

Cylindrical frustules with more or less square (length $15 \mu \mathrm{m}$, diameter $12 \mu \mathrm{m}$ ) toothed valve margins; points arranged in longitudinal rows. 2 cylindrical frustules (length $15 \mu \mathrm{m}$, diameter $12 \mu \mathrm{m}$ ) in chain, with fine granules, dispersed in the center and radiating towards the periphery; denticulated valve margins at cell junction.

Order: Paraliales

Family: Paraliaceae

Paralia sulcata (Ehrenberg) Cleve (Figure 1B)

Syn.: Melosira sulcata Van Heurck

References: $[8,9,10]$

Valve circular, punctuated-areolate (diameter $47 \mu \mathrm{m}$ ). Margin with row appearing as a crown of teeth.

Class: Fragilariophyceae

Order: Fragilariales

Family: Fragilariaceae

Opephora schwartzii (Grunow) Petit (Figure 1C)

References: $[11,12]$

Valve oval to linear (length $28 \mu \mathrm{m}$, diameter $8 \mu \mathrm{m}$ ) with rounded upper apex. Valve surface with coarse areoles (3$4 / 10 \mu \mathrm{m})$ perpendicular to the pseudoraphe.

Order: Striatellales

Family: Striatellaceae

Grammatophora marina (Lyngbye) Kützing (Figure 1D)

References: $[10,13]$

Frustule rectangular (length $=30 \mu \mathrm{m}$, width $=18 \mu \mathrm{m}$ ). Septa slightly undulating (two undulations) with nodule at the ends. 15 striae $/ 10 \mu \mathrm{m}$.

Order: Thalassionematales

Family: Thalassionemataceae

Thalassionema bacillare (Heiden) Kolbe (Figure 1E)

References: $[14,15]$ 
Valve linear (length $82 \mu \mathrm{m}$, diameter $4 \mu \mathrm{m}$ ) slightly expanded in the middle; apex rounded. Axial area distinct; ornementation formed by a row of marginal areolas.

Class: Bacillariophyceae

Order: Mastogloiales

Family: Mastogloiaceae

Mastogloia exigua Lewis (Figure 1F)

References: [16]

Valve lanceolate to linear-lanceolate (length $22 \mu \mathrm{m}$, diameter $10 \mu \mathrm{m}$ ). Presence of 4 larger locules in the middle, with rounded contours.

Order: Achnanthales

Family: Achnanthaceae

Achnanthes brevipes Ag. (Figure 1G-H)

Syn.: Achnanthes seriata Agardh 1827

References: [16]

Inflected frustules (length $52 \mu \mathrm{m}$, diameter $15 \mu \mathrm{m}$ ). Linear-oblong valves with cuneiform apices, slightly constricted in the middle. Raphid valve with roughly punctuated, radiant 8-9/10 $\mu \mathrm{m}$ transapical striae, crossed by longitudinal ribs. Several golden-brown chloroplasts arranged around girdle.

Achnanthes brevipes var. Agardh intermedia (Figure 1I-J)

Syn.: Achnanthes intermedia Kützing 1833

Achnanthes subsessilis Kützing 1833

References: $[10,16]$

Frustules inflected in the middle (length $46 \mu \mathrm{m}$, diameter $12 \mu \mathrm{m}$ ); linear valves with widely rounded apex. Raphid valve with roughly punctured transapical ridges, 6-9/10 $\mu \mathrm{m}$, crossed by irregularly wavy longitudinal ribs. Several goldenbrown chloroplasts arranged around the girdle.

Achnanthes longipes f. lata Agardh? (Figure 1L)

References: [17]

Linear-elliptical to broadly elliptical valves (length $35 \mu \mathrm{m}$, diameter $15 \mu \mathrm{m}$ ) with cuneiform apices, very slightly constrited in the middle with robust ribs; upper valve with pseudo-raphe and lower valve with axial area and narrow stauros.

Achnanthes subconstricta (Meister) Toyoda (Figure 1K)

Syn.: Achnanthes javanica var. subconstricta Meister 1932.

References: [18] 
Valves linear-elliptical (length $80 \mu \mathrm{m}$, diameter $15 \mu \mathrm{m}$ ), constricted in the middle, and slightly curved in cingular view. Cuneiform apices with orbiculi. Striae bi-tetraseriate (4-6 striae/10 $\mu \mathrm{m}$ ) on the both valves.

Family: Cocconeidaceae

Cocconeis scutellum Ehr. (Figure 1M)

Syn.: Rhaphoneis scutellum Ehrenberg 1844

References: $[19,20]$

Valves elliptic; upper valve with large punctuation in radiating lines; lower valve with straight raphe, very straight axial area, small central and rounded; radial striae, finely punctate $(8-10 / 10 \mu \mathrm{m})$, in marginal loculiform crown near the edges.
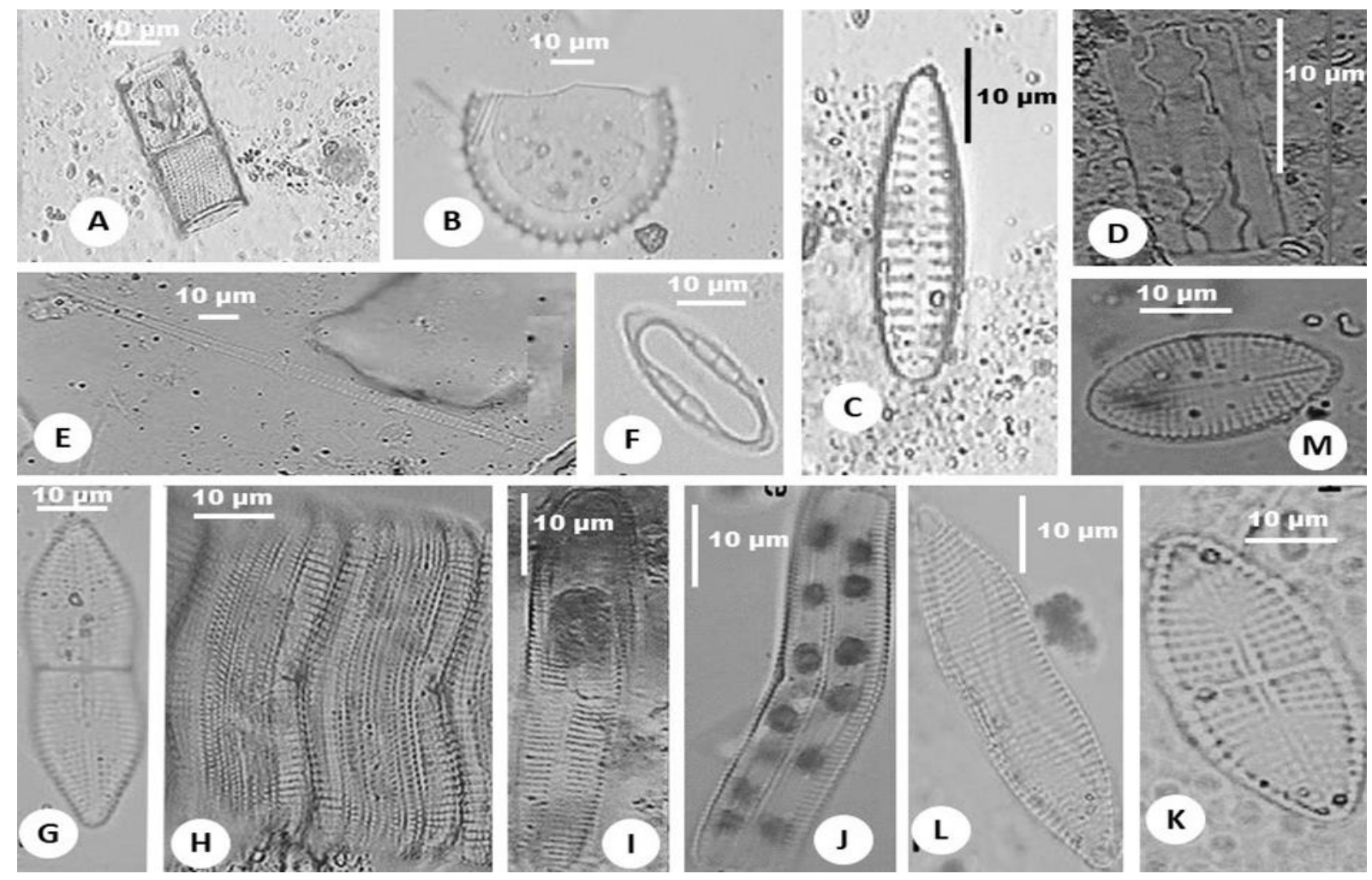

Figure 1 A: Melosira crenulata, girdle view; B: Paralia sulcata, valve view; C: Opephora schwartzii, valve view; D: Grammatophora marina, girdle view; E: Thalassionema bacillare, valve view; F: Mastogloia exigua, valve view; G-H: Achnanthes brevipes, (G) valve view and (H) colony of 2 cells in girdle view; I-J: Achnanthes brevipes var. intermedia, (I) valve view and (J) girdle view; L: Achnanthes longipes f. lata, valve view; K: Achnanthes subconstricta, valve view with orbicles at the apices; M: Cocconeis scutellum, valve view.

Order: Naviculales Bessey, 1907

Family: Diploneidaceae

Diploneis gruendleri (A. Schmidt) Cleve (Figure 1N)

References: [11]

Valve panduriform (length $44 \mu \mathrm{m}$, lobe diameter $20 \mu \mathrm{m}$ ) with deep and tight median constriction. Axial zone bordered by two lines of cells; ribbed-punctuated structure, $8 / 10 \mu \mathrm{m}$. Transverse ribs crossed by longitudinal ribs, interrupted in the middle towards the margin. 

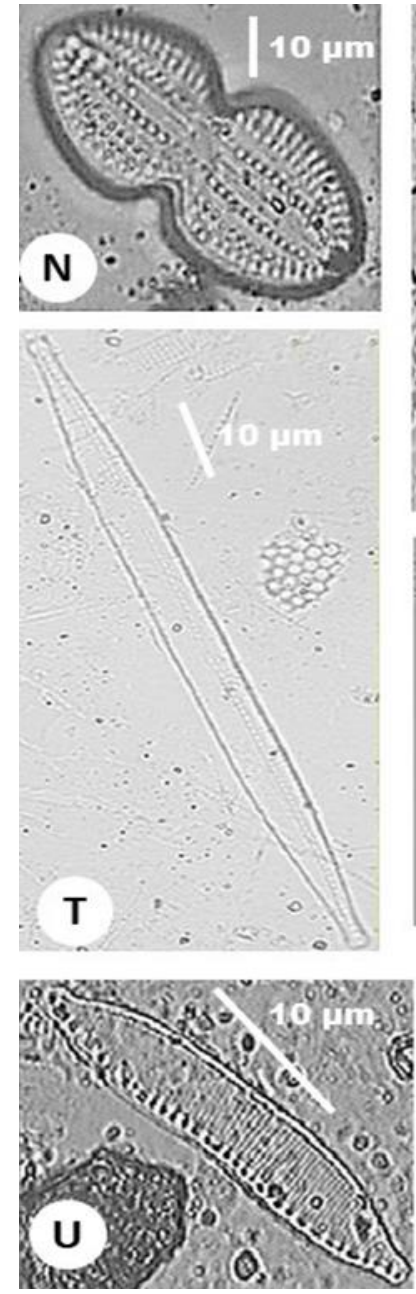
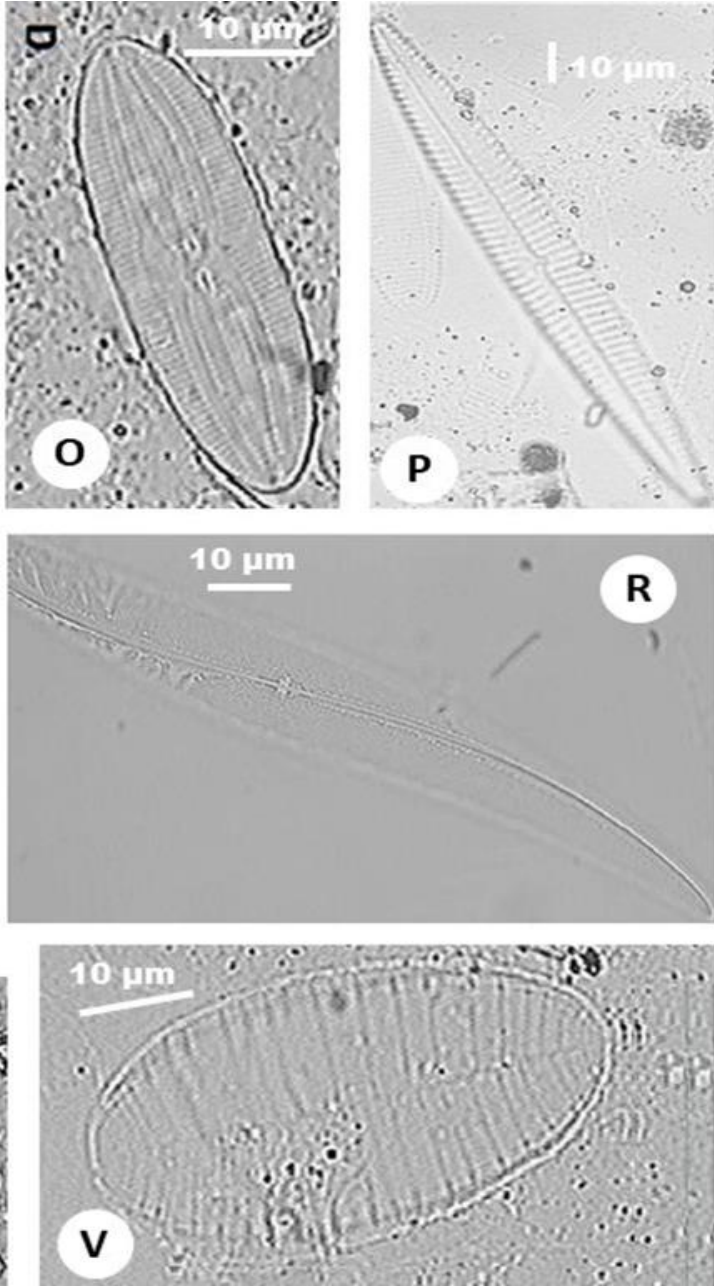
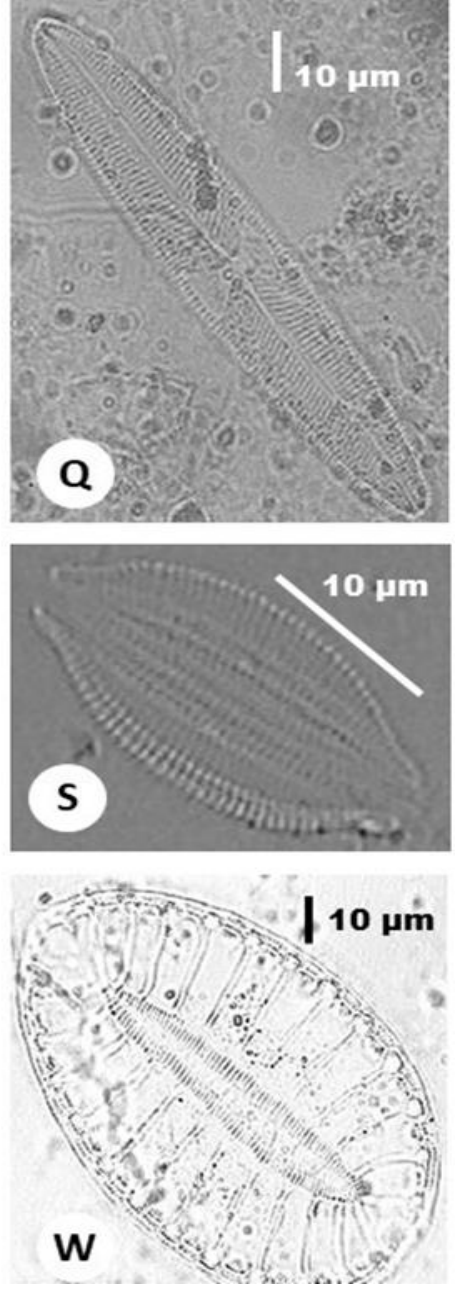

Figure 2 N: Diploneis bombus, valve view; O: Fallacia forcipata, valve view; P: Navicula pennata, valve view; Q: Trachyneis aspera, valve view; A: Pleurosigma diverse-striatum, valve view with central area; S: Amphora turgida, girdle view; T: Nitzschia scalpelliformis; U: Hantzschia amphioxis, valve view; V: Petrodictyon gemma; W: Surirella fastuosa.

Family: Sellaphoraceae

Fallacia forcipata (Greville) Stickle and Mann (Figure 10)

Syn.: Navicula forcipata Grev.M.

References: $[11,12]$

Valve linear (length $38 \mu \mathrm{m}$, diameter $\mu \mathrm{m}$ ) with rounded ends; axial area extended by lateral extensions forming a hyaline $\mathrm{H}$-shaped area, narrowed in the middle, widened towards apices. Valve surface striated.

Family: Naviculaceae

Navicula pennata A. S. (Figure 1P)

References: $[9,21]$

Valve lanceolate (length 50-113 $\mu \mathrm{m}$, diameter 7-14 $\mu \mathrm{m}$ ) subacute to acute with coarse and clearly lineal radiating striae $(5 / 10 \mu \mathrm{m})$; Axial area narrow; central area more or less square with 3 pairs of shorter central ridges. 
Trachyneis aspera Ehr. (Figure 1Q)

Syn.: Trachyneis aspera var. pulchella (Wm. Smith) Cleve, 1894.

References: $[10,22]$

Valves elliptical to linear-elliptical (length $87 \mu \mathrm{m}$, diameter $15 \mu \mathrm{m}$ ) with obtuse rounded apices. Axial area narrow and unilateral; central area stauroneiform; raphe straight. Transapical striae composed of rectangular alveoli, arranged in transverse rows, radiate, $(6-8 / 10 \mu \mathrm{m})$.

Family: Pleurosigmataceae

Pleurosigma diverse-striatum Meister 1935 (Figure 1R)

References: [16, 22]

Valve sigmoid (length $104 \mu \mathrm{m}$, diameter 18-22 $\mu \mathrm{m}$ ), lanceolate in the middle, slightly tapered with rounded apices. Raphe central, strongly sigmoid, eccentric near the apices. Nodule central rounded. 18-19 oblique striae/10 $\mu$ m, 16 transapical striae $/ 10 \mu \mathrm{m}$.

Order: Thalassiophysales

Family: Catenulaceae

Amphora turgida Gregory (Figure 1S)

References: $[10,21]$

Frustules broadly elliptic to orbicular (diameter $12 \mu \mathrm{m}$, length $24 \mu \mathrm{m}$ ) with rostrate ends. Valves semi-lanceolate with right ventral margin, wide and arched dorsal margin; apex slightly produced. Straight raphe near ventral margin; transapical striae parallel in the middle, becoming radiate towards apices, 13/10 $\mu \mathrm{m}$.

Order: Bacillariales

Family: Bacillariaceae

Hantzschia amphioxis (Ehrenberg) Grunow (Figure 1U)

References: $[10,23]$

Valves slightly curved (length $58 \mu \mathrm{m}$, diameter $14 \mu \mathrm{m}$ ); apices slightly attenuated, and rostrous; 5-10 carinal points/10 $\mu \mathrm{m}$; transapical striae punctate, 15-25 / $10 \mu \mathrm{m}$. Raphe eccentric.

Nitzschia scalpelliformis Grunow (Figure 1T)

References: [24]

Valves linear, weakly sigmoid (length 102-115 $\mu$ m, diameter 6-7 $\mu \mathrm{m}$ ) with slightly oblique and round apices. Keel almost central but slightly deflected in at the center of the valve. Fibulae evenly spaced (6-7 fibules/10 $\mu \mathrm{m})$ with two central distant ones.

Order: Surirellales

Family: Surirellaceae

Petrodictyon gemma (Ehrenberg) D. G. Mann (Figure 1V)

Syn.: Surirella gemma Ehr. 
References: $[11,25]$

Valve elliptic ovate with round apices (length $57 \mu \mathrm{m}$, diameter $23 \mu \mathrm{m}$ ). Alae reduced. Axial area very narrow. Costae unevenly spaced, transverse in mid-valve, about $2 / 10 \mu \mathrm{m}$, alternate toward the apices, 5-6/10 $\mu \mathrm{m}$.

Surirella fastuosa (Ehrenberg) (Kützing, 1844) (Figure 1W)

References: $[10,26]$

Cell solitary (length $90 \mu \mathrm{m}$ ), cuneate, with rounded angles. Valves broadly ovate, marginal alae small. Few costae, 1$2 / 10 \mu \mathrm{m}$, dilated towards the margin, becoming narrow towards the broadly lanceolate central area. Valve surface striate (11-12/10 $\mu \mathrm{m}$, striae evident at the margin, and in a narrow band about half-way between the margin and the center of the valve. Narrow striate zone almost parallel with the valve margin.

\subsection{Taxonomic composition}

The results of the study showed that 21 species of diatoms belonging to 18 genera and divided into 13 families, 11 orders and 3 classes were observed. The two most represented families, Achnanthaceae and Diploneidaceae, are each with four species. The families Naviculaceae, Bacillariaceae and Surirellaceae each have two species; the others, with one. Achnanthes is the most representative genera with four species. The large diversity of diatoms in this high salinity environment could be linked to the euryhaline nature of the majority of these taxa [27, 28]. 16 of these 21 diatoms are raphid species (Bacillariophyceae). The dominance of these forms could be due to their higher fixation capacity, based on the excretion of mucilaginous substances through the raphe [29]; which allows them to support, without damage, periods of exondation in regions subject to tidal regime [21].

\section{Conclusion}

This study provided the first detailed list of diatoms in Joal-Fadiouth Lagoon. 21 species belonging to 18 genera and divided into 13 families, 11 orders and 3 classes were inventoried. These diatoms species are new for the microflora of Joal-Fadiouth Lagoon.

\section{Compliance with ethical standards}

\section{Acknowledgments}

The authors are grateful to Mitsubishi Foundation for the financial support during the research works.

\section{Disclosure of conflict of interest}

The authors declare no conflict of interest.

\section{References}

[1] Bengtsson J. (1998). Which species? What kind of diversity? Which ecosystem function? Some problems in studies of relations between biodiversity and ecosystem function. Applied Soil Ecology, 10(3), 191-199.

[2] Queguiner B. (2009). Coastal biogeochemistry. Marseille Oceanology Center, Aix-Marseille University; CNRS; LOPB UMR 6535, Laboratory of Oceanography and Biogeochemistry, OSU / Center of Oceanology of Marseille, 49.

[3] Guiral D, Albaret JJ, Baran E, Bertrand F., Debenay JP, Diouf PS, Guillou JJ, Le Loeuff P, Montoroi JP and Sow M. (1999). Mangrove ecosystems. In: Cormier Salem Marie-Christine (ed.). Rivers of the South: West African societies and mangroves. Paris: IRD, 63-130.

[4] Turmine V. (2000). The dynamics of the coast between Mbour and Joal (Petite Côte-Senegal). Master's thesis, Denis Dinerot University, Paris, 249.

[5] Sakho I. (2011). Evolution and hydro-sedimentary functioning of the Somone lagoon, Petite Côte, Senegal. Doctoral thesis, University of Rouen (France) / Cheikh Anta Diop University of Dakar (Senegal), 252. 
[6] Round FE, Crawford R and Mann DG. (1990). The Diatoms. Morphology and biology of the genera. Cambridge University Press. Cambridge, 747.

[7] Boyer CS. (1916). The Diatomaceæ of Philadelphia and Vicinity, Philadelphia, Press of J.B. Lippincott Co.

[8] Yun SM, Lee SD, Park JS and Lee JH. (2016). A new approach for identification of the genus Paralia (Bacillariophyta) in Korea based on morphology and morphometric analyses. Algae, 31(1), 1-16.

[9] Beltrones DAS and Fuerte FOI. (2006). Epiphytic diatoms associated with red mangrove (Rhizophora mangle) prop roots in Bahía Magdalena, Baja California Sur, Mexico. Rev. Biol. Trop, 54(2), 287-297.

[10] Al-Kandari M, Al-Yamani FY and Al-Rifaie K. (2009). Marine Phytoplankton Atlas of Kuwait's Waters. Lucky Printing Press, Kuwait, 350.

[11] López FFO, Siqueiros BDA and Navarro JN. (2010). Benthic diatoms associated with mangrove environments in the Northwest Region of México, Cicimar-Oceánides, 206.

[12] Stidolph SR, Sterrenburg FAS, Smith KFI and Kraberg A. (2012). Stuart R. Stidolph Diatom Atlas: U.S. Geological Survey Open-File Report 2012-1163.

[13] Moura A, Bittencourt-Oliveira M and Nascimento E. (2007). Benthic Bacillariophyta of Paripe river estuary in Pernambuco state, Brazil. Brazilian Journal of Biology, 67(3), 393-401.

[14] Hasle GR, Syvertsen EE, Steidinger KA, Tangen K and Tomas CR. (1996). Identifying Marine Diatoms and Dinoflagellates. C.R. Tomas. London, Academic Press, 88.

[15] Rivera P, Cruces F and Avaria S. (2006). Thalassionema bacillare (Heiden) Kolbe (Thalassionemataceae, Bacillariophyceae): A special species now unknown to Chilean waters near the phytoplankton near the north. Cienc. Tecnol, 29, 59-70.

[16] Al-Yamani FY and Saburova MA. (2011). Illustrated guide on the benthic diatoms of Kuwait's Marine Environment. Kuwait Institute for Scientific Research, 352.

[17] Peragallo MMH and Peragallo M. (1908). Marine diatoms from France and neighboring maritime districts. Grezsur-Loing (S \& M) Tempère Ed, 540.

[18] Lee SD, Park JS and Lee JH. (2013). Taxonomic study of the genus Achnanthes (Bacillariophyta) in Korean coastal waters. J. Ecol. Environ, 36(4), 391-406.

[19] Cremer H, Sangiorgi F, Wagner-Cremer F, Mc Gee V, Lotter AF and Visscher H. (2007). Diatoms (Bacillariophyceae) and Dinoflagellate Cysts (Dinophyceae) from Rookery Bay, Florida, U.S.A. Caribbean Journal of Science, 43(1), 23-58.

[20] Sar EA. (2003). Cocconeis Ehrenberg and Psammococconeis Garcia (Bacillariophyta) from the Gulf of San Matías, Patagonia, Argentina. Diatom Research, 18(1), 79-106.

[21] Paulmier G. (1997). Atlas of diatomophyceae of French coasts and adjacent oceanic areas. IFREMER report, 439.

[22] Park J, Khim JS, Ohtsuka T, Araki H, Witkowski A and Koh CH. (2012). Diatom assemblages on Nanaura mudflat, Ariake Sea, Japan: with reference to the biogeography of marine benthic diatoms in Northeast Asia. Botanical Studies, 53, 105-124.

[23] Compere P. (1975). Seaweed from the Lake Chad region. IV. Diatomophyceae. Cah. ORSTOM. Ser. Hydrobiol. 9 (4), 203-290.

[24] Al-Handal, AY, Compere P and Riaux-Gobin C. (2016). Marine benthic diatoms in the coral reefs of Reunion and Rodrigues Islands, West Indian Ocean. Micronesica, 3, 1-78.

[25] Ojeda A. (2011). Diatoms of the coastal waters of the Canary Islands. Info. Tec. Inst. Canario Cienc, (14), 219.

[26] Paulmier G. (1993). Microplankton from marine and brackish waters of French Guiana and the West Indies. ORSTOM, Paris, 437.

[27] Pritchard DW. (1967).What is an estuary: a physical viewpoint. American Association for the Advancement of Science, 83, 3-5.

[28] Gama LRM, Masoni MS, Almeida DSIC, Oliveira CE, Ferreira CMM and Terceiro AM. (2011). Microphytoplankton of the Golfão Maranhense Bays and the eastern coast of the State of Maranhão. Bulletin of the Hydrobiology Laboratory, 24(1), 13-26. 
[29] Wetherbee R, Lind JL, Burke J and Quatran RS. (1998).The first kiss: Establishment and control of initial adhesion by raphid diatoms. J. Phycol, 34, 9-15.

\section{How to cite this article}

Gueye M, Ba N, Ngom A, Abdou Salam AM, Mbaye MS and Noba K. (2020). Systematic study of the diatoms (Bacillariophyta) of Joal-Fadiouth Lagoon (Senegal). GSC Biological and Pharmaceutical Sciences, 12(1), 196-204. 